\title{
Reshaping the Banking Sector in Europe
}

\author{
Themistokles Lazarides and Georgia Charitoudi
}

\begin{abstract}
The European banking sector has been under strategic stress for a long time. The paper seeks to find the path that the banking sector in Europe has taken. Also, the paper tries to identify the causes of this significant changes. 6.683 transactions of merger and acquisitions are analysed. Six dimensions of the data were used to give answers to six questions. To answer these questions two approaches have been used. The first approach is a simple pivot table analysis and graphs. The second approach is cluster analysis using Stata (kmeans with (Dis) similarity measure mixed and five (5) groups to be identified). The analysis show that there is a dynamic evolvement through the last two-three decades that created a new market structure. This dynamic is both market and politically driven. The stability of this new structure remains as a question due to the fact that the market is till changing. The banking sector is still consolidating with two distinct characteristics. The first one is the increase of the percentage acquired and the second is the fact that although the trend of consolidation is pan-European, in some countries this trend is even stronger. The fragmented banking system is converging (not yet converged) to a new paradigm to form a new market structure. Finally, the market for corporate control in the banking sector in E.U. seems to react to environmental stimuli.
\end{abstract}

Index Terms-Europe, banking, mergers, acquisitions.

\section{INTRODUCTION}

The banking sector worldwide since the ' 70 s has gone through a transformation. The sector was fragmented, and small local banks were the main paradigm in all major (developed or developing) countries. There were major differences among the different countries for various reasons.

The paper seeks to find the path that the banking sector in Europe has taken and its current status. Also, the paper tries to identify the causes of this significant changes.

Throughout the period of the last forty (40) years there were significant changes in the external environment (political, economic, technological, legal) of banks. In Europe the evolvement of European Common Market into European Union and the continuous effort to converge the member states' political, monetary, legal-regulative and social framework has led to an accelerating changing environment. Furthermore, the adoption of the Euro as the common currency of the majority of the member states and the creation of the European Central Bank were two major factors that imposed change. Finally, the world banking

Manuscript received June 2, 2019; revised September 1, 2019.

Themistokles Lazarides is with University of Thessaly, Larisa, Greece (e-mail: themis@uth.gr).

Georgia Charitoudi is with University of Western Macedonia, Kozani, Greece (e-mail: charitgeo@gmail.com). system has changed through technology, the increase of the intensity of competition, deregulation and regulation (i.e. Basil I, II and III) worldwide and globalization.

These changes of the external environment required a proportional change the inner environment of banks and their strategy. One of the strategies to address the turbulent environment is to merge or to acquire other banks or their assets in order to uphold competitive advantage.

The paper analyses this strategy and tries to identify the causes and the new dynamics of the banking sector in Europe.

\section{The BAnking Sector In Europe}

The European banking system is not as homogenous as the expectations of the policy makers of Europe had hoped ([1]-[3]) or with the global financial - banking system [4].

The last two decades have been decades of rapid changes for the banking system or the banking systems of Europe. There are many differences (in size, ways of operation, ownership, management, etc.). These differences do not seem to be ameliorated or softened through time, at least not as much as to say that the European banking system has converted to a single system. On the contrary, the differences are still observable.

There are four main drivers of change: a) the political will to create a single banking system, b) some threats (e.g. crises of 2001 and 2008) and opportunities (i.e. adoption of Euro) that incurred through time, c) the pressure from the international competition that takes the form of Mergers and Acquisitions (M\&As) and d) the pursuit of the goal of performance and competitive advantage.

The political will, through initiatives such as the adoption of Euro, the creation of the European Central Bank, common regulation, auditing and accounting standards to enforce and to impose a common set environment factors [5] in order to create a homogenous financial market, a common legal regulatory framework and to strengthen a convergence trend.

The adoption of Euro, common regulation, auditing, governance and accounting standards and the concurrent M\&A wave (1998-2004) seem to be the main factors that affected the banking system during this period: facilitated the cross-border provision of financial services and cross-border penetration [6], internationalization of banks and concentration. The real problem-question of these initiatives is whether these initiatives create strengths or weaknesses. Some scholars argue that the European banks seem more fragile now than before. "Pressure from structural regulatory reforms, also Basel III, and the related EUs Capital Requirements Directive (IV) is forcing banks to restrict their business, and boost their regulatory capital and liquidity" ([7] p. 79). The deleveraging of European banks and the 
regulatory pressures will have a significant impact on performance. [8] estimates that bank ROE's is expected to be reduced at the level of $8-10 \%$.

The sovereign debt crisis of 2008 has contributed to the instability of the sector [9]. [10] argues that there is a strong interdependence between sovereign credit and banking systems. [11] found in their empirical study that the crisis had a significant impact on worldwide mergers and acquisitions, and more significantly they found that the emerging market banks acquired banks targeting neighboring countries and European countries.

As a reaction to the crisis the political leadership of Europe has taken measures (e.g. strong regulatory capital restrictions ([12]-[15]) to address the problems that the crisis highlighted. These measures seem to reverse the convergence trend [16]. The impact of the measures was different in the different countries of the European Union The periphery countries under distress (Greece, Portugal, Ireland, Spain, Italy) diverged from the main countries of the European banking system [6]. There is evidence that the crisis of 2008 in some countries has contributed significantly to an intense mergers and acquisition wave.

The pursuit of competitive advantage and performance is one of the factors that led to market restructuring ([17]-[20]). Although the relation and significance of performance and market concentration is ambiguous. [21] show that the goal of profitability - performance is achieved for acquired banks [22]. On the contrary [23] do not find a significant relationship between market consolidation and profitability. A second factor that contributes to performance and competitive advantage is the quality of assets ([24]), liquidity ([14], [25]) and their internal restructuring to improve cost efficiency ([26], [27]). The acquisition of assets is one strategy that needs to be analyzed and to acknowledge if this strategy has been adopted by a significant portion of the banking sector in Europe.

The market for corporate control, Mergers and Acquisitions (M\&As) can contribute to market stability even though the correlation between bank performance and M\&As is tenuous [28]. M\&As activity in the banking sector vary across time and the motives - causes that drive banks to adopt this strategy are accordingly different across time. In the next sections of the paper the activity of M\&As will be presented.

\section{DATA AND METHODS OF ANALYSIS}

The data were collected from Thomson Reuters Eikon database using the specific application for mergers and acquisitions. The data include announcement date, deal size, deal status, target name and nation, acquirer name and nation, form of the transaction target industry, acquirer industry, deal attitude and \% acquired. The search parameters included target European countries and the time period is from 01/10/1983 until 31/12/2018. From the initial sample size collected some transactions with status like dismissed rumor, rumor, seeking target, status unknown and pending for more than one year, were excluded. The final sample 6.683 transactions (5.083 completed and 1.651 not completed).
Unfortunately, the financial - management - governance - ownership data available for any of the parts of the transaction (target or acquirer) were either missing or even if the were recorded they were not enough to facilitate an econometric model.

Six dimensions of the data were used to give answers to six questions:

1. Are there any transactions that were not completed and if so which attitude do they have?

2. Is the deal (transaction) size a factor and how does it changes through time?

3. Which strategy or transaction type were preferable and by whom?

4. Are there any cross-border transactions? If yes where and when are they focused?

5. Are there any difference through the time period of the study of the percentage of the bank acquired?

6 . Is the deal size proportional to the number of deal (transactions)?

To answer these questions two approaches have been used. The first approach is a simple pivot table analysis and graphs. The second approach is cluster analysis using Stata (kmeans with (Dis)similarity measure mixed and five (5) groups to be identified).

\section{ANALYSIS AND DisCUSSION}

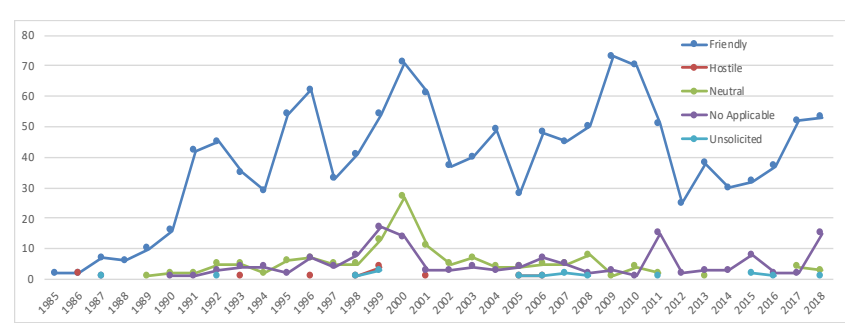

Fig. 1. Not completed deals - deal attitude (1983-2018).

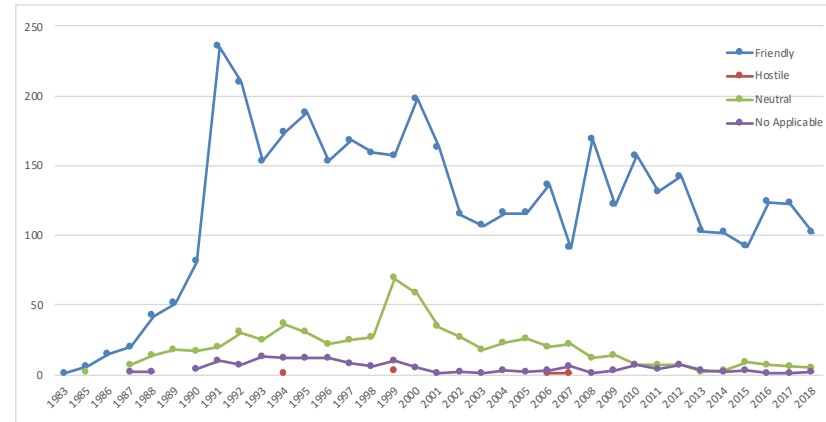

Fig. 2. Completed deals - deal attitude (1983-2018).

Each question highlights a different dimension of the phenomenon of M\&As (all tables are presented in the Appendix section of the paper). The not completed transactions (24,7\% of the total recorded deals) even though not completed, they have an important analytical value (see Fig. 1). The majority of them $(80,44 \%)$ were friendly M\&As and only $0,73 \%$ hostile. As Fig. 2 the periods with the highest reported deal numbers are identical with the periods of important events (political and economic) in Europe (1995-1996, 2000, 2009). This the case for the completed deals as well with the main difference that completed deals 
show a clear downward trend after 1990. This trend is understandable due to the fact that there not many new banks added during this period and the total number of targets available is declining through time.

The majority of the not completed deals as for the form of the transactions were: Acquisition of Assets (29\%), Acquisition of Partial Interest (26,7\%) and Mergers (18,5\%). There is not a clear indication of the strategy intended due to mix of the forms, but the distribution (see Fig. 3) of the deals (completed or not) show an immediate reaction of the banking sector to environment stimuli.

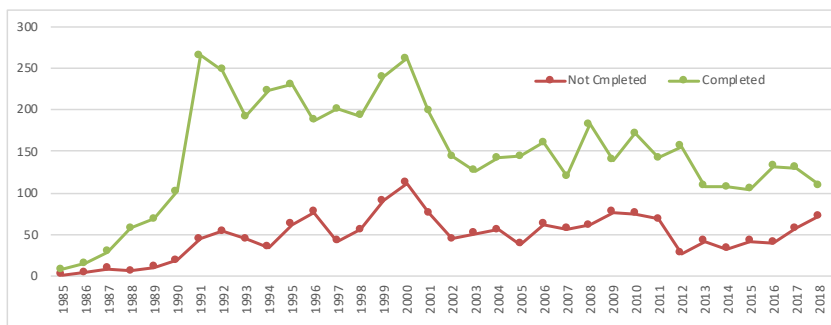

Fig. 3. Total number of completed and not completed deals (1985-2018).

The combination of the form of the transactions and percentage of bank acquired reveals, in part, the strategy that the acquiring bank uses. Fig. 4 shows that the general trend of the mean of percentage acquired is upward, while the trend of the number of deals is downward. That suggests that the strategy is evolving and that the goal is the consolidation of the sector.

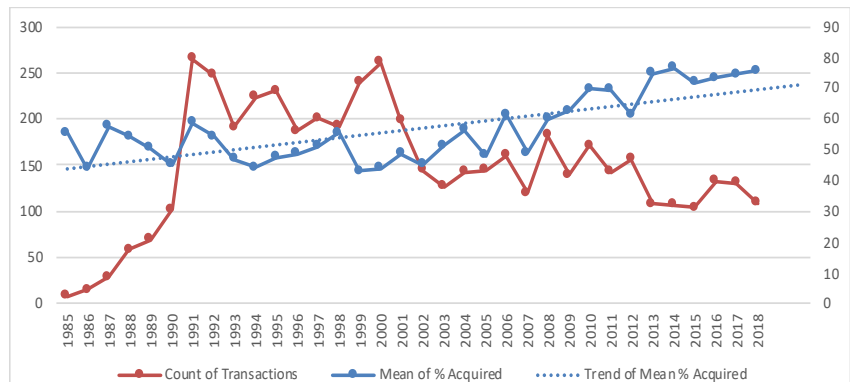

Fig. 4. Average \% acquired (1985-2018).

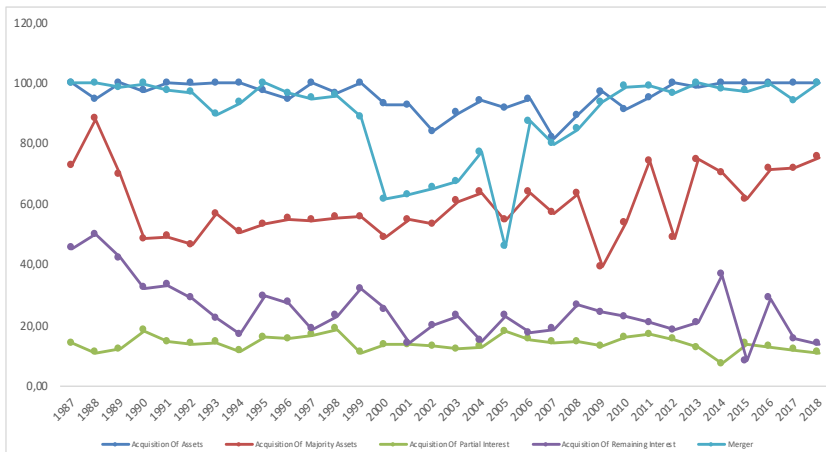

Fig. 5. Total number of completed and not completed deals (1985-2018).

The analysis of the average to its components the acquisition of partial interest remains (see Fig. 5) stable with a small downward trend. All other forms of transaction show an upward trend of the percentage acquired. This finding corresponds with the previous one.

The fact that Europe is part of an open corporate environment means that European Union banks can be targets of M\&As by banks located outside of its borders. There are two separate questions that need to be answered. The first one is from which area of the world are interested in investing the banking sector of Europe? The statistics show that only $11 \%$ of the transactions involve cross-border M\&As (i.e. the acquiring bank is not located in a European Union country). Hence, the majority of the M\&A activity is concentrated amongst European Union countries.

The majority of the inward M\&A activity is focused in five (5) European Union countries (Germany, France, Italy, Spain and United Kingdom) (see Fig. 6). In these countries there is major difference between the number of transactions and the sum of the deal size. Two factors can explain this difference a) the fact that the banking sector in these countries was greatly fragmented and b) they are the main banking centers of the European Union and amongst the countries with the highest GDP in the European Union.

Fig. 7 illustrates that there is an upward trend both in number and percentage acquired from banks located outside of the European Union and hence the activity intensifies through time. These countries' M\&A activity represent the $59,5 \%$ of the total number of transactions and the $69 \%$ of the sum of the deal size made.

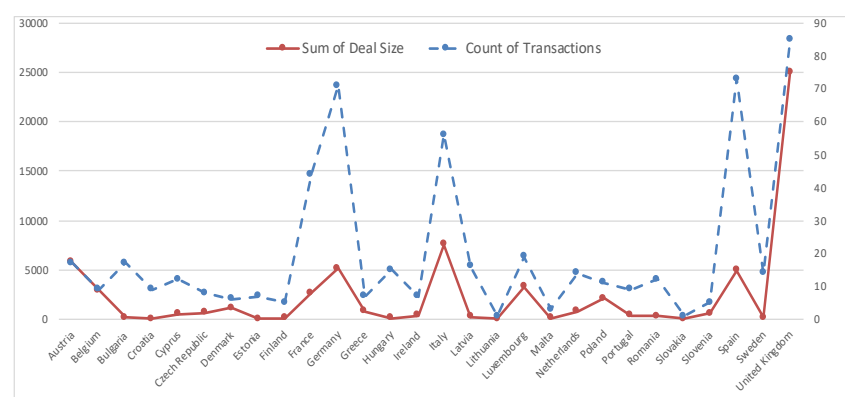

Fig. 6. Total number and deal size of cross-border M\&As (1985-2018).

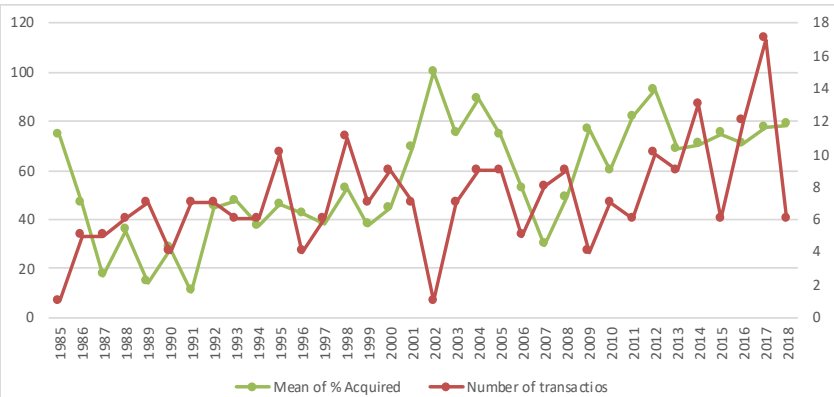

Fig. 7. Total number and mean of $\%$ acquired of cross-border M\&As (1985-2018)

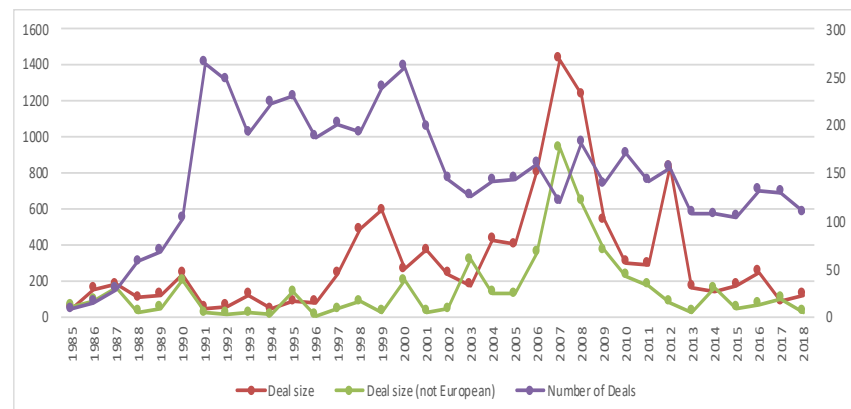

Fig. 8. Average deal size of M\&As (1985-2018).

The average deal size (in mil. \$) has a very different distribution from the number of deals (see Fig. 8). The deal 
size is high at specific time periods (1999, 2007-2008, 2012) which correspond with specific events (mainly political and market regulation). One interesting finding is that the average deal size is in almost the whole period of the study below the average. That suggests that the intra-Europe M\&As are larger in deal size than the ones from outside Europe.

Table I shows that there is a uneven distribution of the activity. Acquiring banks located in North America are involved in more than one third of the transactions and almost half of the sum of the deal size. Another interesting finding is that there is a significant difference between the number of transactions and the sum of deal size for the acquiring banks located in rest of Europe, Asia, Arabia and China. In the first two cases (rest of Europe and Asia) the number of transactions is proportionally larger than the sum of deal size, that means that acquiring banks from these regions are targeting smaller banks. The opposite happens for the banks located in Arabia and China. Chinese and Arabian banks target large banks in the European Union.

TABLE I: CROSS-BORDER TRANSACTIONS

\begin{tabular}{ccc}
\hline \hline & Number of Transactions & Deal Size (mil. \\
& $2,90 \%$ & $3,56 \%$ \\
\hline Africa & $2,36 \%$ & $20,38 \%$ \\
Arabia & $11,23 \%$ & $3,61 \%$ \\
Asia & $2,17 \%$ & $3,15 \%$ \\
Australia & $2,90 \%$ & $14,27 \%$ \\
China & $13,41 \%$ & $2,91 \%$ \\
Rest of Europe & $36,05 \%$ & $44,32 \%$ \\
North America & $18,84 \%$ & $4,50 \%$ \\
Not available & $6,34 \%$ & $1,33 \%$ \\
Russia & $3,80 \%$ & $1,98 \%$ \\
South America & &
\end{tabular}

Using cluster analysis five cluster have been identified. In order to specify the characteristics of this clusters an analysis of five dimensions (time, attitude, number of transactions, region of acquiring bank and sum of deal size) of the sample is necessary.

The dimension of time (see Fig. 9) shows that two groups (3 and 4) have a very different behavior from the others Group three has a very high acquiring percentage and the fourth has the lowest.

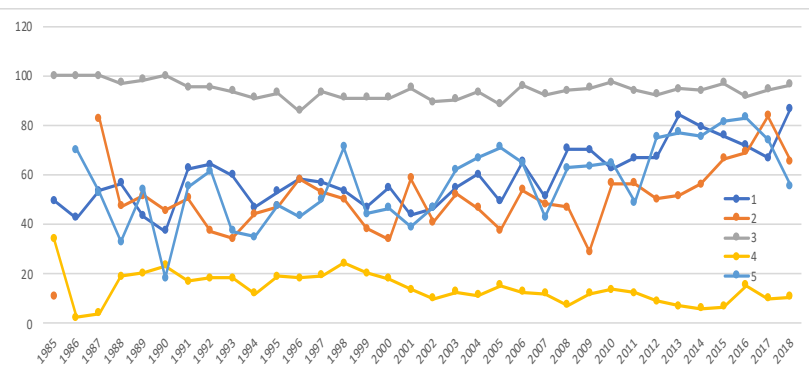

Fig. 9. Cluster groups and Time (1985-2018).

Using the dimension of attitude, group three (3) has the highest concentration (in terms of deal size) in hostile $(88,52 \%)$ and friendly $(37,24 \%)$ M\&As and group four (4) in neutral $(47,26 \%)$. Group one (1) has the highest number of transactions and the highest concentration in the form of Acquisition of Certain Assets (65,3\% of the sum of deal size) and Acquisition (100\%). Group four (4) has the highest concentration in Acquisition of Partial Interest $(68,41 \%)$ and Acquisition of Remaining Interest $(56,92 \%)$ and group three (3) in Acquisition of Assets $(47,63 \%)$, Acquisition of Majority Assets (45,82\%), Merger (59,58\%).

As of the sum of deal size, group three (3) has the largest concentration and the lowest is reported for group five (5). Finally, the dimension of the origin of the acquirer, group one (1) has the largest concentration from the European Union. Group two (2) is focused solely in intra-European Union transactions, group one (1) attracts investors from all regions (especially Australia, Arabia, North and South America) except the rest of Europe and Russia, which are the preferred origins for group three (3) and four (4) and finally group five (5) originates from Asia, Africa and China.

So, the analysis of the five clusters (see Table II in the Appendix) shows that there are distinctive characteristics for each cluster or group. This is an indication of application of different strategies by different clusters and there is no unique strategy for all by all (target and acquirers).

TABLE II: CLUSTER CHARACTERISTICS

\begin{tabular}{|c|c|c|c|c|c|}
\hline & 1 & 2 & 3 & 4 & 5 \\
\hline Percentage & & & High & High & \\
\hline Attitude & & & $\begin{array}{c}\text { Friendly, } \\
\text { Hostile }\end{array}$ & Neutral & \\
\hline Deals & High & & & & \\
\hline $\begin{array}{c}\text { Form of } \\
\text { Transactio } \\
n\end{array}$ & $\begin{array}{c}\text { Acquisition } \\
\text { of Certain } \\
\text { Assets, } \\
\text { Acquisition }\end{array}$ & & $\begin{array}{c}\text { Acquisition } \\
\text { of Partial } \\
\text { Interest, } \\
\text { Acquisition } \\
\text { of Remaining } \\
\text { Interest }\end{array}$ & $\begin{array}{c}\text { Acquisition } \\
\text { of Assets, } \\
\text { Acquisition } \\
\text { of Majority } \\
\text { Assets, } \\
\text { Merger }\end{array}$ & \\
\hline Deal Size & & & Largest & & Lowest \\
\hline Origin & $\begin{array}{c}\text { EU, } \\
\text { Australia, } \\
\text { Arabia, } \\
\text { North and } \\
\text { South } \\
\text { America }\end{array}$ & $\begin{array}{l}\mathrm{E} \\
\mathrm{U}\end{array}$ & $\begin{array}{l}\text { rest of } \\
\text { Europe and } \\
\text { Russia }\end{array}$ & $\begin{array}{c}\text { rest of } \\
\text { Europe and } \\
\text { Russia }\end{array}$ & $\begin{array}{c}\text { Asia, } \\
\text { Africa } \\
\text { and } \\
\text { China }\end{array}$ \\
\hline
\end{tabular}

\section{CONCLUSION}

The paper focused on highlighting the dynamics of the banking sector in European Union. The banking sector is still consolidating with two distinct characteristics. The first one is the increase of the percentage acquired and the second is the fact that although the trend of consolidation is pan-European, in some countries this trend is even stronger.

As [29] argue this may be attributed to better institutional laws with regard to financial markets, taxation and corporate governance. The majority of the M\&As targets and acquirers originate from E.U. itself. It looks like that EU banking system is imploding. The fact that banks located in European Union's countries are targeted for M\&As by banks located outside its borders may be caused by the fact that there are major international banking sectors in E.U. and furthermore the E.U. is one of the leading economies worldwide.

The fragmented banking system is converging (not yet converged) to a new paradigm to form a new market structure. Finally, the market for corporate control in the banking sector in E.U. seems to react to environmental stimuli.

The fact of consolidation and the reaction to stimuli 
doesn't mean that the banking sector is better off now than it was previously. Further research is needed to establish whether the new market structure creates a more stable environment.

\section{CONFLICT OF INTEREST}

The authors declare no conflict of interest.

\section{AUTHOR CONTRIBUTIONS}

Themistokles Lazarides conducted the research (data collection, preparation of data, econometric analysis) and co-wrote the paper. Georgia Charitoudi co-wrote the paper; all authors had approved the final version.

\section{REFERENCES}

[1] L. Weill, "Convergence in banking efficiency across European countries," Journal of International Financial Markets, Institutions and Money, vol. 19, no. 5, pp. 818-833, 2009.

[2] E. Mamatzakis, C. Staikouras, and A. Koutsomanoli-Filippaki, "Bank efficiency in the new European Union member states: Is there convergence?" International Review of Financial Analysis, vol. 17, no. 5, pp. 1156-1172, 2008.

[3] D. Dahl, R. E. Shrieves, and M. F. Spivey, "Convergence in the activities of European banks," Journal of International Financial Markets, Institutions and Money, vol. 18, no. 2, pp. 161-175, 2008.

[4] S. Herrmann and A. Winkler, "Real convergence, financial markets, and the current account-Emerging Europe versus emerging Asia," The North American Journal of Economics and Finance, vol. 20, no. 2, pp. 100-123, 2009

[5] P. Maria and E. Mamatzakis, "What drives bank performance in transitions economies? The impact of reforms and regulations," Research in International Business and Finance, vol. 39, Part A, pp. 578-594, 2017.

[6] D. Schoenmaker and T. Peek, "The state of the banking sector in Europe," OECD Economics Department Working Papers, No. 1102, OECD Publishing, 2014.

[7] P. Molyneux, "Structural reform, too-big-to fail and banks as public utilities in Europe," in Financial Crisis, Bank Behaviour and Credit Crunch, Springer International Publishing, 2016, pp. 67-80.

[8] A. Saunders. (2014). Is Basel turning banks into public utilities? [Online]. Available: http://ssrn.com/ abstract $1 / 42475627$

[9] E. Drimpetas and Lazarides, "The impact of sovereign debt ratings to bank ratings and financial performance of the banking system," in $A$ New Growth Model for the Greek Economy: Requirements for Long-Term Sustainability, Palgrave McMilan, 2015, ch. 19.

[10] B. Moro, "The European twin sovereign debt and banking crises," in Financial Crisis, Bank Behaviour and Credit Crunch, Springer International Publishing, 2016, pp. 67-80.

[11] R. Rao-Nicholson and J. Salaber, "Impact of the financial crisis on cross-border mergers and acquisitions and concentration in the global banking industry," Thunderbird International Business Review, vol. 58, no. 2, pp. 161-173, 2016.

[12] O. Isaiah, "Impact of regulatory capital on European banks financial performance: A review of post global financial crisis," Research in International Business and Finance, vol. 44, pp. 309-318, 2018.

[13] M. E. Barth, J. G. Biscarri, R. Kasznik, and G. López-Espinosa. (2016). Bank earnings and regulatory capital management using available for sale securities. [Online]. Available: https://papers.ssrn.com/sol3/papers.cfm?abstract_id $=2448482$

[14] A. N. Berger, C. H. Bouwman, T. Kick, and K. Schaeck, "Bank liquidity creation following regulatory interventions and capital support," Journal of Financial Intermediation, vol. 26, pp. 115-141, 2016.

[15] A. Demirguc-Kunt, E. Detragiache, and O. Merrouche, "Bank capital: Lessons from the financial crisis," Journal of Money, Credit and Banking, vol. 45, no. 6, pp. 1147-1164, 2013.
[16] T. Lazarides, "Performance of European banks: Crisis, corporate governance and convergence," Corporate Governance and Sustainability Review, vol. 1, no. 2, pp. 43-49, 2017.

[17] A. N. Berger, B. Imbierowicz, and C. Rauch, "The roles of corporate governance in bank failures during the recent financial crisis," Journal of Money, Credit and Banking, vol. 48, no. 4, pp. 729-770, 2016.

[18] G. N. Weiß, S. Neumann, and D. Bostandzic, "Systemic risk and bank consolidation: International evidence," Journal of Banking \& Finance, vol. 40, pp. 165-181, 2014.

[19] Y. Altunbaş and D. Marqués, "Mergers and acquisitions and bank performance in Europe: The role of strategic similarities," Journal of Economics and Business, vol. 60, no. 3, pp. 204-222, 2008.

[20] J. P. Bonin, I. Hasan, and P. Wachtel, "Bank performance, efficiency and ownership in transition countries," Journal of Banking \& Finance, vol. 29, no. 1, pp. 31-53, 2005.

[21] D. Focarelli, F. Panetta, and C. Salleo, "Why do banks merge?" Journal of Money Credit, and Banking, vol. 34, no. 4, pp. 1047-1066, 2002.

[22] A. N. Berger and C. H. Bouwman, "How does capital affect bank performance during financial crises?" Journal of Financial Economics, vol. 109, no. 1, pp. 146-176, 2013.

[23] Goldberg and Rai "The structure-performance relationship for European banking," Journal of Banking \& Finance, vol. 20, issue 4, pp. 745-771, 1996.

[24] A. Pennathur and S. Vishwasrao, "The financial crisis and bank-client relationships: Foreign ownership, transparency, and portfolio selection," Journal of Banking \& Finance, vol. 42, pp. 232-246, 2014.

[25] A. Dietrich, K. Hess, and G. Wanzenried, "The good and bad news about the new liquidity rules of Basel III in Western European countries," Journal of Banking \& Finance, vol. 44, pp. 13-25, 2014.

[26] F. Pasiouras, S. Tanna, and C. Zopounidis, "The impact of banking regulations on banks' cost and profit efficiency: Cross-country evidence," International Review of Financial Analysis, vol. 18, no. 5, pp. 294-302, 2009.

[27] A. Ismail, I. Davidson and R. Frank, "Operating performance of European bank mergers," The Service Industries Journal, vol. 29, no.3, pp. 345-366, 2009.

[28] K. Dua and N. Simb, "Mergers, acquisitions, and bank efficiency: Cross-countryevidence from emerging markets," Research in International Business and Finance, vol. 36, pp. 499-510, 2016.

[29] E. Xie, K. S. Reddy, and J. Liang, "Country-specific determinants of cross-border mergers and acquisitions: A comprehensive review and future research directions," Journal of World Business, vol. 52, no. 2, pp. 127-183, 2017.

Copyright $\odot 2020$ by the authors. This is an open access article distributed under the Creative Commons Attribution License which permits unrestricted use, distribution, and reproduction in any medium, provided the original work is properly cited (CC BY 4.0).

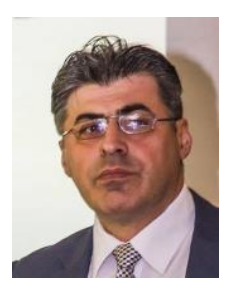

Themistokles Lazarides was born in Florina Greece in 1969. He is an economist with an M.B.A. and he holds a Ph.D. in corporate governance. Currently, he is an associate professor at University of Thessaly (Greece) and his research interests focus on corporate governance, corporate collapses, crisis, ethics, regulation, auditing, merger and acquisitions.

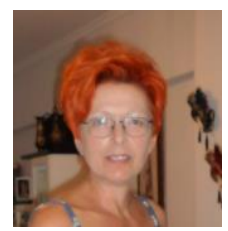

Georgia Charitoudi was born in 1958 in Tashkent, Uzbekistan. She holds a B. Sc. in applied mathematics and mechanics (University of Tashkent, Uzbekistan) and a Ph.D. in physics and mathematics sciences, University of Tashkent, Uzbekistan. She is currently a professor at the University of Western Macedonia (Greece) and her research interests focus on information systems, accounting and corporate social responsibility. 